\title{
WATER DIURESIS IN CHILDREN AGED 1-3 YEARS
}

\author{
BY \\ H. SCHNIEDEN \\ From the Department of Pharmacology, University of Bristol
}

(RECEIVED FOR PUBLICATION DECEMBER 14, 1956)

It is now well established that newborn animals and infants are unable to excrete as great a percentage of a test dose of water as adults of the same species (Table 1). The age at which this function of the kidney matures in human beings has been varyingly assessed as 3 months (Ames, 1953) to between 6 and 10 years (Ohlmann, 1920). It therefore seemed of interest to see what percentage of a water load given by mouth is excreted by children aged 1-3 years, especially as this may be of clinical interest in controlling intravenous fluid therapy in this age group.

Moreover the choice of parameter for comparing renal functions in adults and infants is still in doubt. McCance and Widdowson (1952) advocate in theory the use of total body water as a parameter but in practice use body weight. Smith (1951) states that 'there is no a priori basis upon which to select any one standard of reference, body weight, surface area, or kidney weight'. However, Smith has some slight preference for kidney weight, and he points out that in man the correlation between kidney weight and surface area is greater than between kidney weight and height or body weight. Other workers (Barnett, Vesterdal, McNamara and Lauson (1952), Calcagno, Rubin and Weintraub (1954) prefer to use body surface as a measure of comparison between renal functions of adults and infants. Barnett $e t$ al. (1952) state that the failure of others to observe water diuresis in young infants may have been due to 'comparison being made between adults and infants who were given doses of water equivalent on a weight rather than a surface basis'.

In view of these difficulties two parameters (body weight and surface area) were used in the present investigation.

TABLE 1

WATER DIURESIS IN NEWBORN ANIMALS AND IN MAN

\begin{tabular}{|c|c|c|c|c|c|}
\hline Species & Age & Authors & $\begin{array}{l}\text { Water Load } \\
\text { (ml./100 g. } \\
\text { Body Weight) }\end{array}$ & \% Water Load & $\begin{array}{c}\text { Period of Observation } \\
\text { (min.) }\end{array}$ \\
\hline \multirow{2}{*}{ Rat } & $\begin{array}{l}1-2 \text { days } \\
7-8 \text { days } \\
14-16 \text { days } \\
\text { Adults }\end{array}$ & Heller (1947, 1951) & 4-5 & $\left.\begin{array}{l}20 \text { (approx.) } \\
30 \text { (approx.) } \\
55 \text { (approx.) } \\
85 \text { (approx.) }\end{array}\right\}$ & 145 \\
\hline & $\begin{array}{l}\text { Newborns } \\
4 \text { days } \\
12 \text { days } \\
\text { Adults }\end{array}$ & $\begin{array}{l}\text { McCance and Wilkinson } \\
\text { (1947) }\end{array}$ & 5 & $\left.\begin{array}{l}13 \cdot 4^{*} \\
40 \cdot 8^{*} \\
55 \cdot 0^{*} \\
39 \cdot 2^{*}\end{array}\right\}$ & 180 \\
\hline Guinea-pig & $\begin{array}{l}\text { Newborn } \\
\text { Adult }\end{array}$ & Dicker and Heller (1951) & 5 & $\left.\begin{array}{r}50 \\
115\end{array}\right\}$ & 180 \\
\hline Dog & $\begin{array}{l}2 \text { days } \\
8 \text { days } \\
25 \text { days }\end{array}$ & Adolph (1943) & 5 & $\left.\begin{array}{r}40 \text { (approx.) } \\
80 \text { (approx.) } \\
100 \text { (approx.) }\end{array}\right\}$ & 240 \\
\hline \multirow{4}{*}{ Man } & $\begin{array}{l}\text { Newborn } \\
3 \text { days } \\
7 \text { days }\end{array}$ & Ames (1953) & 3 & $\left.\begin{array}{l}10 \text { (approx.) } \\
35 \text { (approx.) } \\
50 \text { (approx.) }\end{array}\right\}$ & 180 \\
\hline & $\begin{array}{l}\text { 6-18 days } \\
\text { Adults }\end{array}$ & McCance et al. (1954) & 5 & $\left.\begin{array}{l}55 \text { (approx.) } \\
95 \text { (approx.) }\end{array}\right\}$ & 240 \\
\hline & Newborns to 3 months old & Aschenheim (1919) & $200 \mathrm{ml}$. per child & 23-77 (approx.) & 240 \\
\hline & $\begin{array}{l}\text { Newborns-3 months old } \\
\text { 3-6 months old }\end{array}$ & Ohlmann (1920) & $\begin{array}{l}200 \mathrm{ml} \text {. per child } \\
200 \mathrm{ml} \text {. per child }\end{array}$ & 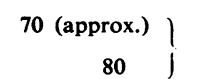 & 240 \\
\hline
\end{tabular}

* Recalculated from data. 
Methods

The renal response to water was tested by the method of Fishberg (1939). Sixteen children were the main subject of the investigation, none of them had any evidence of renal, hepatic or cardiac disease and they were all at the end of a period of convalescence. They were fasted overnight (12 hours) and on the following morning a catheter was inserted. Eight children were then given $860 \mathrm{ml}$. water $/ \mathrm{m}^{2}$ body surface by stomach tube. A further eight children received $22.0 \mathrm{ml}$. water $/ \mathrm{kg}$. body weight. The total water load of five children included in the latter group contained $25 \mathrm{ml}$. of deuterium oxide. Virtual deuterium space was calculated from the deuterium concentration of specimens of urine obtained between the second and third hours after the water load had been given. Urine specimens were collected hourly. Deuterium was estimated by a photoneutron method
(Haigh, 1954; Haigh and Schnieden, 1956). Nine healthy adults were also tested after a similar overnight fast. These lay down on reaching the laboratory and only got up to pass urine. Following the procedure of McCance, Naylor and Widdowson (1954) they were not catheterized. Urinary osmotic pressure was measured by estimating freezing point depression. The specific gravity of the urine was estimated using an urinometer but when the volume of urine for estimation was small the method of Heller (1940) was used. Four children and one adult were rejected from the series because they vomited following the administration of water.

\section{Results}

Tables 2-4 show that the maximum concentrations of urines obtained from the children after

TABLE 2

RENAL RESPONSE TO A WATER LOAD OF $860 \mathrm{ML}$./M2 BODY SURFACE IN ADULTS

\begin{tabular}{|c|c|c|c|c|c|c|c|c|}
\hline $\begin{array}{c}\text { Patient } \\
\text { No. }\end{array}$ & Sex & $\begin{array}{c}\text { Age } \\
\text { (Yr.) }\end{array}$ & Diagnosis & $\begin{array}{c}\text { Total } \\
\text { Water Load } \\
\text { (ml.) }\end{array}$ & $\begin{array}{c}\text { Water } \\
\text { Load } \\
(\mathrm{ml} . / \mathrm{kg} .)\end{array}$ & $\begin{array}{l}\% \text { Water Load } \\
\text { Excreted in } \\
3 \text { Hours }\end{array}$ & $\begin{array}{c}\text { Maximum } \\
\text { Concentration } \\
\text { of Urine (Sp.G.) }\end{array}$ & $\begin{array}{c}\text { Minimum } \\
\text { Concentration } \\
\text { of Urine (Sp.G.) }\end{array}$ \\
\hline $\begin{array}{l}1 \\
2 \\
3 \\
4 \\
5 \\
6 \\
7 \\
8 \\
9\end{array}$ & $\begin{array}{l}\mathbf{M} \\
\mathbf{M} \\
\mathbf{M} \\
\mathbf{M} \\
\mathbf{M} \\
\mathbf{M} \\
\mathbf{M} \\
\mathbf{M} \\
\mathbf{M}\end{array}$ & $\begin{array}{l}22 \\
35 \\
24 \\
23 \\
19 \\
27 \\
23 \\
21 \\
29\end{array}$ & $\begin{array}{cc}\text { Healthy } & \text { adult } \\
\text {, } & , \\
\text { ", } & \text { ", } \\
\text { " } & \text { ", } \\
\text { " } & , \\
\text {," } & \text {," }\end{array}$ & $\begin{array}{l}1,720 \\
1,560 \\
1,500 \\
1,500 \\
1,600 \\
1,500 \\
1,650 \\
1,560 \\
1,590\end{array}$ & $\begin{array}{l}20 \cdot 2 \\
22 \cdot 5 \\
26 \cdot 0 \\
22 \cdot 0 \\
25 \cdot 6 \\
22 \cdot 0 \\
22 \cdot 1 \\
22 \cdot 8 \\
24 \cdot 2\end{array}$ & $\begin{array}{r}109 \\
106 \\
103 \\
111 \\
118 \\
107 \\
110 \\
85 \\
104\end{array}$ & $\begin{array}{l}1 \cdot 023 \\
1 \cdot 024 \\
1 \cdot 024 \\
1 \cdot 024 \\
1 \cdot 012 \\
1 \cdot 020 \\
1 \cdot 023 \\
1 \cdot 025 \\
1 \cdot 017\end{array}$ & $\begin{array}{l}1 \cdot 002 \\
1 \cdot 001 \\
1 \cdot 001 \\
1 \cdot 002 \\
1 \cdot 001 \\
1 \cdot 001 \\
1 \cdot 002 \\
1 \cdot 001 \\
1 \cdot 001\end{array}$ \\
\hline
\end{tabular}

TABLE 3

RENAL RESPONSE TO A WATER LOAD OF 860 ML./M² BODY SURFACE IN CHILDREN

\begin{tabular}{|c|c|c|c|c|c|c|c|c|c|c|c|}
\hline \multirow{2}{*}{$\begin{array}{c}\text { Patient } \\
\text { No. }\end{array}$} & \multirow[t]{2}{*}{ Sex } & \multirow[t]{2}{*}{$\begin{array}{l}\text { Age } \\
(\mathrm{yr} .)\end{array}$} & \multirow{2}{*}{$\begin{array}{l}\text { Diagnosis: } \\
\text { Convalescent } \\
\text { from }\end{array}$} & \multirow{2}{*}{$\begin{array}{l}\text { Total } \\
\text { Water } \\
\text { Load } \\
\text { (ml.) }\end{array}$} & \multirow[t]{2}{*}{$\begin{array}{r}\text { Load } \\
\text { (ml./kg.) }\end{array}$} & \multicolumn{2}{|c|}{$\begin{array}{l}\% \text { Water } \\
\text { Load } \\
\text { Excreted in }\end{array}$} & \multicolumn{2}{|c|}{$\begin{array}{c}\text { Maximum } \\
\text { Concentration } \\
\text { of Urine }\end{array}$} & \multicolumn{2}{|c|}{$\begin{array}{c}\text { Minimum } \\
\text { Concentration } \\
\text { of Urine }\end{array}$} \\
\hline & & & & & & 3 Hours & 4 Hours & Sp.G & $\operatorname{mos} M / 1$ & Sp.G. & $\operatorname{mos} M / 1$ \\
\hline $\begin{array}{l}10 \\
11 \\
12 \\
13 \\
14 \\
15 \\
16 \\
17\end{array}$ & $\begin{array}{l}\mathbf{M} \\
\mathbf{F} \\
\mathbf{M} \\
\mathbf{M} \\
\mathbf{F} \\
\mathbf{M} \\
\mathbf{M} \\
\mathbf{M}\end{array}$ & $\begin{array}{lr}2 & 2 / 12 \\
2 & 1 / 12 \\
2 & 2 / 12 \\
2 & 2 / 12 \\
2 & 11 / 12 \\
2 & \\
2 & 6 / 12 \\
1 & 10 / 12\end{array}$ & $\begin{array}{l}\text { Bronchopneumonia } \\
\text { Primary T.B. } \\
\text { Tonsillitis } \\
\text { Cervical gland } \\
\text { Bronchopneumonia } \\
\text { Gastroenteritis } \\
\text { Bronchopneumonia } \\
\text { Bronchopneumonia }\end{array}$ & $\begin{array}{l}430 \\
450 \\
430 \\
437 \\
500 \\
450 \\
470 \\
370\end{array}$ & $\begin{array}{l}32 \cdot 6 \\
35 \cdot 5 \\
38 \cdot 5 \\
42 \cdot 0 \\
36 \cdot 9 \\
38 \cdot 2 \\
36 \cdot 1 \\
31 \cdot 2\end{array}$ & $\begin{array}{r}82 \\
93 \\
81 \\
77 \\
89 \\
104 \\
101 \\
64\end{array}$ & $\begin{array}{r}84 \\
95 \\
82 \\
82 \\
91 \\
105 \\
104 \\
69\end{array}$ & $\begin{array}{l}1.021 \\
1.022 \\
1.002 \\
1.025 \\
1.023 \\
1.016 \\
1.017 \\
\text { N.D. }\end{array}$ & $\begin{array}{l}813 \\
796 \\
748 \\
824 \\
749 \\
792 \\
\text { 623 } \\
\text { N.D. }\end{array}$ & $\begin{array}{l}1 \cdot 001 \\
1.001 \\
1.002 \\
1.002 \\
1.002 \\
1.001 \\
1.001 \\
1 \cdot 003\end{array}$ & $\begin{array}{r}65 \\
59 \\
45 \\
97 \\
48 \\
86 \\
54 \\
161\end{array}$ \\
\hline
\end{tabular}

TABLE 4

RENAL RESPONSE TO A WATER LOAD OF 22 ML./KG. BODY WEIGHT IN CHILDREN

\begin{tabular}{|c|c|c|c|c|c|c|c|c|c|c|c|c|}
\hline \multirow{2}{*}{$\begin{array}{l}\text { Patient } \\
\text { No. }\end{array}$} & \multirow[t]{2}{*}{ Sex } & \multirow{2}{*}{\multicolumn{2}{|c|}{ Age }} & \multirow{2}{*}{$\begin{array}{l}\text { Diagnosis : } \\
\text { Convalescent } \\
\text { from }\end{array}$} & \multirow{2}{*}{$\begin{array}{l}\text { Total } \\
\text { Water } \\
\text { Load } \\
\text { (ml.) }\end{array}$} & \multirow{2}{*}{$\begin{array}{l}\text { Water } \\
\text { Load } \\
(\mathrm{ml} . / \mathrm{m} .)\end{array}$} & \multicolumn{2}{|c|}{$\begin{array}{c}\text { Water } \\
\text { Load } \\
\text { Excreted in }\end{array}$} & \multicolumn{2}{|c|}{$\begin{array}{l}\text { Maximum } \\
\text { Concentration } \\
\text { of Urine }\end{array}$} & \multicolumn{2}{|c|}{$\begin{array}{l}\text { Minimum } \\
\text { Concentration } \\
\text { of Urine }\end{array}$} \\
\hline & & & & & & & 3 Hours & 4 Hours & Sp.G. & $\operatorname{mos} M / 1$ & Sp.G. & $\operatorname{mos} M / 1$ \\
\hline $\begin{array}{l}18^{*} \\
19^{*}\end{array}$ & $\begin{array}{l}\mathbf{F} \\
\mathbf{M}\end{array}$ & & $\begin{array}{l}6 / 12 \\
5 / 12\end{array}$ & $\begin{array}{l}\text { Otitis media } \\
\text { Upper respiratory in- } \\
\text { fection }\end{array}$ & $\begin{array}{l}235 \\
210\end{array}$ & $\begin{array}{l}47 \cdot 0 \\
44 \cdot 5\end{array}$ & $\begin{array}{r}60 \\
113\end{array}$ & $\begin{array}{r}67 \\
118\end{array}$ & $\begin{array}{l}1 \cdot 020 \\
1 \cdot 019\end{array}$ & $\begin{array}{l}714 \\
732\end{array}$ & $\begin{array}{l}1 \cdot 003 \\
1 \cdot 001\end{array}$ & $\begin{array}{r}134 \\
54\end{array}$ \\
\hline $20^{*}$ & $\mathbf{M}$ & 2 & $9 / 12$ & $\begin{array}{l}\text { Admitted ? petit mal, } \\
\text { no evidence found }\end{array}$ & 275 & $45 \cdot 5$ & 103 & 108 & $1 \cdot 015$ & 670 & $1 \cdot 001$ & 62 \\
\hline $\begin{array}{l}21^{*} \\
22^{*} \\
23 \\
24^{*} \\
25\end{array}$ & $\begin{array}{l}\mathbf{F} \\
\mathbf{F} \\
\mathbf{M} \\
\mathbf{M} \\
\mathbf{M}\end{array}$ & $\begin{array}{l}1 \\
2 \\
2 \\
1 \\
2\end{array}$ & $\begin{array}{l}2 / 12 \\
7 / 12 \\
9 / 12 \\
7 / 12 \\
5 / 12\end{array}$ & $\begin{array}{l}\text { Pneumonia } \\
\text { Otitis media } \\
\text { Anaemia } \\
\text { Pneumonia } \\
\text { Bronchitis }\end{array}$ & $\begin{array}{l}220 \\
255 \\
272 \\
215 \\
268\end{array}$ & $\begin{array}{l}50 \cdot 0 \\
52 \cdot 1 \\
46 \cdot 5 \\
53 \cdot 1 \\
48 \cdot 5\end{array}$ & $\begin{array}{r}73 \\
85 \\
101 \\
88 \\
54\end{array}$ & $\begin{array}{l}78 \\
\text { N.D. } \\
109 \\
100 \\
59\end{array}$ & $\begin{array}{l}1 \cdot 024 \\
1 \cdot 017 \\
1 \cdot 023 \\
1 \cdot 021 \\
1 \cdot 024\end{array}$ & $\begin{array}{l}870 \\
660 \\
790 \\
754 \\
615\end{array}$ & $\begin{array}{l}1 \cdot 001 \\
1 \cdot 001 \\
1.001 \\
1 \cdot 003 \\
1 \cdot 003\end{array}$ & $\begin{array}{r}62 \\
154 \\
51 \\
129 \\
97\end{array}$ \\
\hline
\end{tabular}


withdrawal of food and water for 12 hours does not differ significantly from those in adults (mean \pm S.E.: adults, $1 \cdot 022 \pm 0.002$; children, $1.021 \pm 0.002)$, $\mathrm{t}=0.5, \mathrm{P}>0 \cdot 5)$.

The minimum concentration of urine obtained in the adults varied between a specific gravity of 1.001 and 1.002 whilst the minimum concentration in children varied between $1 \cdot 001$ and $1 \cdot 003$.

Fig. 1 shows that infants aged $1 \frac{1}{2}-3$ years who

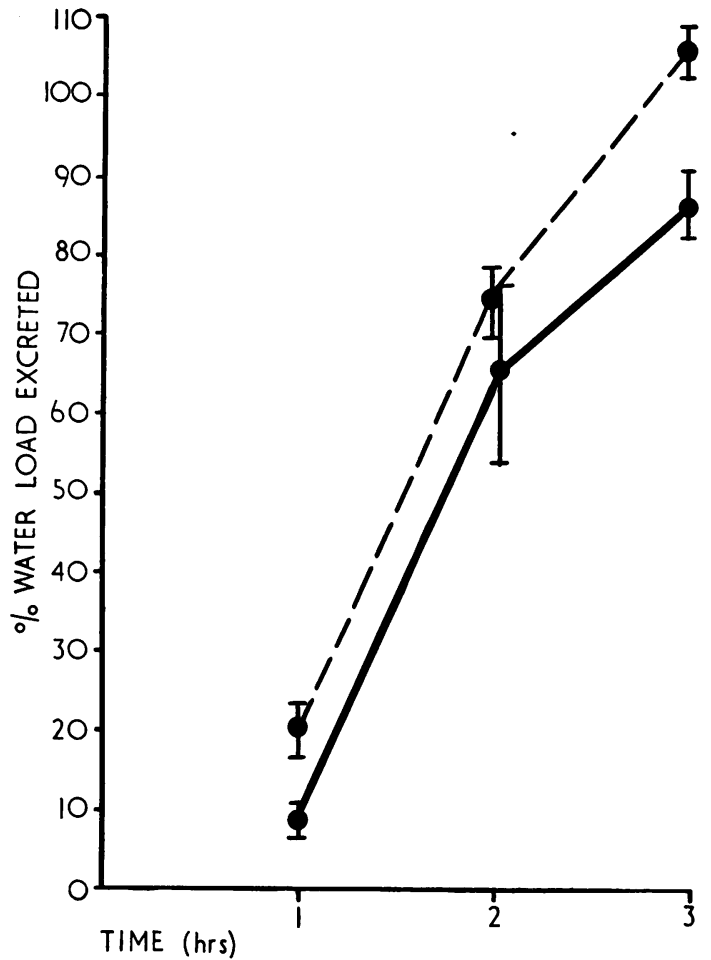

Fig. 1. - The renal response (mean \pm S.E.) to water of a group of eight children between the ages of $1 \frac{1}{2}$ and 3 years. - - - adults. $\bullet-1$ children.

were given a water load of $860 \mathrm{ml} . / \mathrm{m}^{2}$ did not in three hours excrete as much of their water load as adults (mean \pm S.E.: adults, $105 \cdot 9 \pm 3 \cdot 0$; children, $86 \cdot 4 \pm 4 \cdot 6, \mathrm{t}=3.63, \quad \mathrm{P}>0.001)$. The difference remains significant (children, $89 \cdot 5 \pm 4 \cdot 0$; adults, $105 \cdot 9 \pm 3 \cdot 0, t=3 \cdot 3, P>0 \cdot(01)$, even if infant 17 , who was under 2 years old, is excluded. In fact Tables 2-4 show that the percentage of the water load excreted by the children in four hours did not quite attain that excreted by the adults in three hours.

Children of the same age group who were given a water load of $22 \mathrm{ml} . / \mathrm{kg}$. excreted in three hours $84 \cdot 6 \pm 5 \cdot 8 \%$ of their water load only and in four hours $91 \cdot 3 \pm 8 \cdot 7 \%$ as compared with the excretion of $105.9 \pm 3.0$ by adults in three hours. The difference is again significant at three hours $(\mathrm{t}=3 \cdot 2, \mathrm{P}>0 \cdot 001)$.

The mean virtual deuterium space in five infants was $62 \cdot 6 \pm 1 \cdot 7 \%$ of the total body weight (Table 5 ). These results are in good agreement with those of Friis-Hansen, Holiday, Stapleton and Wallace (1951) who found that in five children aged 1 year 3 months tc 3 years 10 months, deuterium space varied between $58 \cdot 2$ and $62 \cdot 8 \%$ of their body weight.

\section{Discussion}

The results obtained indicated that in children up to the age of 3 years the capacity for water diuresis lay between that of newborn infants and adults although it clearly approached that of adults rather than of infants. This conclusion applied whether the water load was given in relation to surface area or to the body weight of the child.

McCance et al. (1954) advocated the use of total body water as a parameter. Assuming, as they did, that a $70 \mathrm{~kg}$. man has 42 litres of body water (equals $60 \%$ of the body weight), a water load of $1,500 \mathrm{ml}$. (which equals a load of $22.0 \mathrm{ml}$. $/ \mathrm{kg}$. body weight or $860 \mathrm{ml} . / \mathrm{m}^{2}$ if the surface area of such a person is taken as $1.73 \mathrm{~m}^{2}$ ) represents a water load per litre of body water of $35.5 \mathrm{ml}$. In the present series the water load per litre of body water given to infants 18-24 varied from 32.5 to $38.5 \mathrm{ml}$. (mean \pm S.E., $35 \cdot 2+1 \cdot 1)$. This suggests that the water load per litre body water was much the same in the experiments on adults (Table 2) as in the children of group 18-25, although there was a significant difference in water diuresis.

The results of this investigation are more in keeping with those of Ohlmann (1920) than those of Ames (1953). The former found that five children aged between 1 and 4 years excreted an average of

TABLE 5

VIRTUAL DEUTERIUM SPACE (TOTAL BODY WATER) IN FIVE CHILDREN

\begin{tabular}{c|c|c|c}
\hline Patient No. & Virtual Deuterium Space $(\%$ body weight) & Total Water Load (ml.) & Water Load/Litre Body Water \\
\hline 18 & $56 \cdot 9$ & 235 \\
19 & $64 \cdot 8$ & 210 & 275 \\
20 & $61 \cdot 2$ & 220 & $34 \cdot 5$ \\
21 & $62 \cdot 1$ & 215 & $36 \cdot 0$ \\
24 & $67 \cdot 9$ & $35 \cdot 1$ \\
\end{tabular}


$68 \%$ of their water load. However, the procedure employed by Ohlmann (1920) differed appreciably from that of Ames (1953): Ohlmann gave $400 \mathrm{ml}$./ child whilst Ames gave $30 \mathrm{ml} . / \mathrm{kg}$. body weight.

Other tests of kidney function suggest that renal maturation is not complete for several years after birth. Smith (1951) states that the inulin clearance, the renal plasma flow and the maximal rate of tubular p-aminohippuric acid excretion do not attain adult levels until the child is at least 2 years old.

It may be argued that the children investigated were not healthy. Whilst it is not denied that they all had been recently ill, they had all recovered and were fit for discharge on the day after the test. It is unlikely therefore that the difference of approximately $20 \%$ found between the urinary excretion of water by the children and adults is due to their previous illness. But since, as Heeley and Talbot (1955) have shown, the insensible water loss per day is considerably higher in infants than in adults, it may have been due to that difference.

\section{Summary}

The renal response to water of 16 children between the ages of $1 \frac{1}{2}$ and 3 years was tested. Eight children received a water load of $850 \mathrm{ml} . / \mathrm{m}^{2}$ body surface, the others a water load of $22.0 \mathrm{ml} . / \mathrm{kg}$. body weight. The children concentrated their urine as well as adults but, in contrast to adults, did not excrete a volume of urine equal to that of the test dose within three hours. The virtual deuterium oxide space in five children was determined. The question of parameters for the study of kidney functions is discussed.

I would like to thank Professor A. V. Neale and Dr. J. Apley of the Bristol Royal Hospital for Sick Children for permission to investigate their patients and also the medical students who kindly participated in the investigation. I am grateful to Professor $\mathrm{H}$. Heller for his criticisms and to Dr. C. P. Haigh for the estimations of deuterium.

\section{REFERENCES}

Adolph, E. F. (1943), Physiological Regulations, Lancaster, Pa. Ames, R. G. (1953). Pediatrics, 12, 272

Aschenheim, E. (1919). Z. Kinderheilk. (Orig.), 24, 281

Barnett, H. L., Vesterdal, J., McNamara, H. and Lauson, H. D. (1952) Amer. J. Dis. Child., 84, 481.

Calcagno, P. L., Rubin, M. I. and Weintraub, D. H. (1954). J. clin. Invest., 33, 91.

Dicker, S. E. and Heller, H. (1951). J. Physiol. (Lond.), 112, 149.

Fishberg, A. M. (1939). Hypertension and Nephritis, 4th ed. Philadelphia.

Friis-Hansen, B. J., Holiday, M., Stapleton, T. and Wallace, W. M. (1951). Pediatrics, 7, 321.

Haigh, C. P. (1954). Radioisotope Conference, 1954, p. 101.

- and Schnieden, H. (1956). J. Physiol. (Lond.), 131, 377.

Heeley, A. M. and Talbot, N. B. (1955). Amer. J. Dis. Child., 90, 251 .

Heller, H. (1940). J. Physiol. (Lond.), 98, 3P. (1947). Ibid., 106, 245.

- (1951). Archives of Disease in Childhood, 26, 195.

McCance, R. A. and Wilkinson, E. (1947). J. Physiol. (Lond.), 106, 256.

- and Widdowson, E. M. (1952). Lancet, 2, 860.

-, Naylor, N. J. B. and Widdowson, E. M. (1954). Archives of Disease in Childhood, 29, 104.

Ohlmann, J. (1920). Z. Kinderheilk. (Orig.), 26, 291.

Smith, H. W. (1951). The Kidney. New York. 